\title{
Effect of partial replacement of dried, wet cull dates and date pits instead of yellow corn, supplemented with feed additives on growth performances of Nile tilapia (Oreochromis niloticus).
}

\author{
Hafz, A. Mabrouk' ${ }^{1}$ Mohamad, A. Zaki ${ }^{2}$; Abd El-Aziz, M. Nour ${ }^{2}$ \\ and Eman, H. Labib ${ }^{3}$ \\ 1- National Institute of Oceanography \& Fisheries, Alexandria, Egypt. \\ 2- Animal production Dept., Faculty of Agric. Alex. Univ. Alex., Egypt. \\ 3- Animal Production Research Institute, Agriculture research Center, Dokki, \\ Giza, Egypt.
}

\begin{abstract}
A 12-week feeding trials were conducted to evaluate the nutritive value of Atwo forms of palm cull date and date pits as energy sources, supplemented with feed additives (Phytogenics), to be partially replaced (13.5\%) yellow corn in feeding Nile tilapia fingerlings. Twelve experimental isonitrogenous $(30.43 \%$ crude protein), isocaloric (436.43 kcal GE 100g-1) experimental diets were formulated taking into account energy sources and feed additives. Concerning energy source, four experimental diets were formulated which contain: yellow corn (YC) as control diet, dried cull date (DCD), wet cull date (WCD) and date pits (DP). As for feed additives (flavorings), three dietary sub-groups were builtup in each group to include: zero additives, $0.03 \%$ Digestarom $\AA$ (DG) and 0.03 $\%$ Marjoram leaf extract (MLE). Ten fingerlings $(10.55 \pm 0.30 \mathrm{~g})$ were stocked/aquarium; two replicates per treatment and fed twice daily (six days) at $3 \%$ of body weight for 84 days.

The results indicated that the partial replacement (13.5\%) of WCD instead of YC supplemented with or without feed additives increased fish specific growth rate and feed utilization. However, replacement either DCD or DP decreased tilapia performances; meanwhile DP recorded the worst values. On the other hand, DG supplementation improved fish performances either fed WCD-based diets or control diets (YC). It could be concluded that wet cull date may be cost-effective when partially replaces yellow corn in tilapia diets as energy source, and improves fish performances when supplements with $0.03 \%$ Digestarom ${ }^{\circledR}$.
\end{abstract}

Keywords: Cull Date, date pits, phytogenic, additives, growth performance, feed utilization, Oreochromis niloticus.

\section{INTRODUCTION}

Yellow corn has been a traditional energy source in fish feeds but, rising costs and its scarcity make it increasingly uneconomical. Therefore, there is need to search for other suitable ingredients that can be used as energy sources that are protein saving instead of yellow corn with a manner that achieves 
benefit for fish farming. On the other hand, availability of quality fish feed ingredients constitutes a great challenge for fish nutritionists (Sotolu, 2010; Sotulo et al., 2011). Several studies have been investigated the potential using of date pits (Yousif et al., 1996; Osman et al., 2001; El-Sayed et al., 2006), cull dates (Srour et al., 2002; Nour et al., 2004; Azaza et al., 2008, 2009), byproducts (Sotolu and Faturoti, 2009), and feed additives (Mabrouk et al., 2008, 2011a,b) in fish feeds. In addition, many of fish producers cannot afford to supplement fish diets with the highly expensive feed additives (Oladotun et al., 2003); therefore, the use of organic-based feed additives to improve feed utilization efficiency in aquaculture. The use of date and date pits as fish feed source was first mentioned by Yousif et al., (1996). The nutritional value of date fruit (Phoenix dactylifera) is high, contains a high percentage of carbohydrate (total sugars, 44-88\%), fat, comprising 14 types of fatty acids $(0.2-0.5 \%), 15$ salts and minerals, protein; contains 23 different amino acids (2.3-5.6\%), six vitamins and a high percentage of dietary fiber (6.4-/11.5\%) (Al-Shahib and Marshall, 2003). A number of by-products are becoming available in date packing and processing operations (cull dates, date pits, kernel and press cakes). According to different references, date pits chemically composed of $5-10 \%$ moisture, $5-7 \%$ crude protein, $7-10 \%$ oil, $10-20 \%$ crude fiber, $55-65 \%$ carbohydrates and 1-2\% ash (FAO, 1999).

Concerning feed additives, Digestarom is a phytogenic flavoring material designed to offer a natural supplement to antimicrobial growth and health enhancers for livestock and poultry (Halle et al., 2004). Simultaneously, the aromatic leaves, either fresh or dry, are the used part of sweet Marjoram (Majorana hortensis) (Chiej, 1984) which is widely used as flavouring for salad dressings, vegetables, legumes and oils (Bown, 1995). It has been shown that aqueous and methanolic extracts from sweet marjoram contain multiple compounds with considerable antimicrobial action (Janicsak et al., 1999; Fecka and Turek, 2008).

Thus, the aim of the present study is to evaluate the effects of partial replacement (13.5\%) of dried cull dates (DCD), wet cull dates (WCD) and date pits (DP) instead of yellow corn with or without addition of $0.03 \%$ feed additives (Marjoram leaf extract or Digestarom ${ }^{\circledR}$ ) on growth performance, feed utilization and carcass composition of Nile tilapia (O.niloticus ) fingerlings. 


\section{Experimental design:}

\section{MATERIALS AND METHODS}

The applied nutritional treatments are summarized in the following table.

Table 1: nutritional treatments

\begin{tabular}{|c|c|c|c|c|}
\hline \multirow{2}{*}{$\begin{array}{c}\text { Feed } \\
\text { additive }\end{array}$} & \multicolumn{4}{|c|}{ Energy source } \\
\cline { 2 - 5 } & YC & DCD & WCD & DP \\
\hline Zero & F1 & F4 & F7 & F10 \\
\hline MLE & F2 & F5 & F8 & F11 \\
\hline DG & F3 & F6 & F9 & F12 \\
\hline
\end{tabular}

YC: Yellow corn DCD: Dry cull date WCD: Wet cull date

DP: Date pits $\quad$ MLE: Marjoram leaf extract DG: Digestarom ${ }^{\circledR}$

Nile tilapia fingerlings purchased from Barseek Fish Hatchery, El-Behera Governorate. Fish were placed randomly in twenty four glass aquaria $(100 \times 40 \times 30 \mathrm{~cm}, 1001$ water volume capacity /aquarium), two replicates per treatment. Fingerlings were counted, weighed to the nearest gram/fish and stocked at 10 fingerlings/aquarium $(10.55 \pm 0.30 \mathrm{~g} /$ fingerling). Experimental fish were fed on a basal diet for one week as adaptation period and once the adaptation period was completed, fish in each aquarium were reweighed, and their initial weights were recorded. Thereafter, fish in each aquarium were fed on the experimental diets twice daily (six days) at 3\% of body weight for 84 days.

All aquaria were cleaned daily in order to prevent accumulation of fecal materials and clean dechlorinated fresh water was added to reset water volume. All aquaria were provided with aeration using air blower; water temperature was thermostatically controlled at $28 \pm 1^{\circ} \mathrm{C}$ during the experimental period. Water quality parameters, total ammonia, nitrites and nitrates, total alkalinity, chloride $\mathrm{pH}$ were mearured.

\section{Phytogenics:}

Two phytogenic commercial products were used separately, mixed and homogenized with the experimental diets:

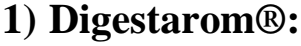

Digestarom ${ }^{\circledR}(\mathrm{DG})$ was added to $\mathrm{F} 3, \mathrm{~F} 6, \mathrm{~F} 9$ and $\mathrm{F} 12$ at $0.03 \%$ in the form of dry powder.

\section{2) Marjoram leaf (Majorana hortensis):}

Marjoram leaf extract (MLE) was prepared according to Thakare (2004) procedure. It was added to F2, F5, F8 and F11 at $0.03 \%$ in the form of liquid.

\section{Experimental diets:}

Twelve isonitrogenous (30.43\% crude protein), isocaloric (436.43 kcal GE $100 \mathrm{~g}-1)$ experimental diets were formulated taking into account energy sources and feed additives. Concerning energy source, four dietary groups were formulated to contain: $45 \%$ yellow corn (YC) as control diet, $13.5 \%$ dried cull date (DCD), $13.5 \%$ wet cull date (WCD) and $13.5 \%$ date pits (DP) according to 
Osman et al. (2001). Table (2) illustrates formulation of the experimental diets, while Table (3) illustrates proximate analysis (\%).

Table 2: Composition of the experimental diets (\%).

\begin{tabular}{|c|c|c|c|c|c|c|c|c|c|c|c|c|}
\hline \multirow{4}{*}{ Ingredient } & \multicolumn{12}{|c|}{ Diets } \\
\hline & \multicolumn{3}{|c|}{$\mathrm{YC}$} & \multicolumn{3}{|c|}{ DCD } & \multicolumn{3}{|c|}{ WCD } & \multicolumn{3}{|c|}{ DP } \\
\hline & 0 & MLE & DG & 0 & MLE & DG & 0 & MLE & DG & 0 & MLE & DG \\
\hline & F1 & F2 & F3 & F4 & F5 & F6 & F7 & F8 & F9 & F10 & F11 & F12 \\
\hline Fish meal & 23 & 23 & 23 & 23 & 23 & 23 & 23 & 23 & 23 & 23 & 23 & 23 \\
\hline Soybean meal & 29 & 29 & 29 & 29 & 29 & 29 & 29 & 29 & 29 & 29 & 29 & 29 \\
\hline $\begin{array}{l}\text { Yellow corn } \\
\text { (YC) }\end{array}$ & 45 & 45 & 45 & 31.50 & 31.50 & 31.50 & 31.50 & 31.50 & 31.50 & 31.50 & 31.50 & 31.50 \\
\hline $\begin{array}{l}\text { Dried cull date } \\
\text { (DCD) }\end{array}$ & - & - & - & 13.5 & 13.5 & 13.5 & - & - & - & - & - & - \\
\hline $\begin{array}{l}\text { Wet cull date } \\
\text { (WCD) }\end{array}$ & - & - & - & - & - & - & 13.5 & 13.5 & 13.5 & - & - & - \\
\hline Date pits (DP) & - & - & - & - & - & - & - & - & - & 13.5 & 13.5 & 13.5 \\
\hline MLE & - & 0.03 & - & - & 0.03 & - & - & 0.03 & - & - & 0.03 & - \\
\hline DG & - & - & 0.03 & - & - & 0.03 & - & - & 0.03 & - & - & 0.03 \\
\hline Soybean oil & 2 & 2 & 2 & 2 & 2 & 2 & 2 & 2 & 2 & 2 & 2 & 2 \\
\hline $\begin{array}{l}\text { Vit. } 1 \text { and } \\
\text { min2. Mix. }\end{array}$ & 1 & 1 & 1 & 1 & 1 & 1 & 1 & 1 & 1 & 1 & 1 & 1 \\
\hline Total & 100 & 100 & 100 & 100 & 100 & 100 & 100 & 100 & 100 & 100 & 100 & 100 \\
\hline
\end{tabular}

YC: Yellow corn. DCD: Dried cull date. WCD: Wet cull date.

MLE: Marjoram leaf extract. DG: Digestarom.

DP: Date pits.

Control diets (without phytogenic additives): F1, F4, F7, and F10

MLE incorporated diets: F2, F5, F8, and F11

DG incorporated diets: F3, F6, F9, and F12

1Vitamin mixture/kg premix containing the following: 3300IU vitamin A, vitamin D3, 410 IU

vitamin E,2660mg vitamin B1,133mg vitamin B2,580 mg vitamin B6 ,410 mg vitamin B12

,50mg biotin $9330 \mathrm{mg}$ Colin chloride, 4000mg vitamin C, $2660 \mathrm{mg}$ Inositol, $330 \mathrm{mg}$ para- amino benzoic acid, $9330 \mathrm{mg}$ niacin, $26.60 \mathrm{mg}$ pantothenic acid.

2Mineral mixture/kg premix containing $325 \mathrm{mg}$ Manganese, $200 \mathrm{mg}$ Iron, $25 \mathrm{mg}$ Copper, $5 \mathrm{mg}$ Iodine, $5 \mathrm{mg}$ Cobalt.

Table 3: Proximate analysis of the experimental diets (\%).

\begin{tabular}{|c|c|c|c|c|c|c|c|c|c|c|c|c|}
\hline \multirow[b]{2}{*}{ Item } & \multicolumn{12}{|c|}{ Diet No. } \\
\hline & F1 & F2 & F3 & F4 & F5 & F6 & F7 & F8 & FO & F10 & F11 & F12 \\
\hline DM\% $\%$ & 90.91 & 90.93 & 90.95 & 9078 & 90.80 & 90.83 & 90.54 & 90.55 & 90.59 & 90.65 & 90.64 & 90.67 \\
\hline rude & 30.49 & 30.48 & 30.49 & 30.40 & 30.42 & 30.43 & 30.43 & 30.45 & 30.43 & 30.38 & 30.36 & 30.37 \\
\hline Ether $\mathrm{e}$ & 6.27 & 6.29 & 6.30 & 6.25 & 6.23 & 6.26 & 6.49 & \begin{tabular}{|l|}
6.47 \\
\end{tabular} & 6.46 & 6.18 & 6.17 & 6.16 \\
\hline & 7.71 & 7.73 & 7.75 & 85 & 8.57 & 8.53 & 8.80 & 8.83 & 8.81 & 8.90 & 8.92 & 8.90 \\
\hline Crude & 4.89 & 4.90 & 4.91 & $5.1 !$ & 5.21 & 5.20 & 5.03 & 5.05 & 504 & 4.59 & 4.60 & 4.58 \\
\hline $\mathrm{NFE} \%$ & 50.64 & 50.60 & 50.55 & 49.61 & 49.57 & 49.58 & 49.28 & 49.20 & 49.26 & 49.95 & 49.95 & 49.99 \\
\hline & 439.8 & 439.8 & 439.7 & 434.85 & 434.6 & 435. & 435.93 & 435.5 & 435. & 435.5 & 435.3 & 435.4 \\
\hline $0(\mathrm{mg} \mathrm{CP} / \mathrm{kccl} \mathrm{G}$ & 69.33 & 69.30 & 69.34 & 69.91 & 69.99 & 69.94 & 69.80 & 69.92 & 69.86 & 69.76 & 60.75 & 69.75 \\
\hline
\end{tabular}

Control diets (without phytogenic additives): F1, F4, F7, and F10

MLE incorporated diets: F2, F5, F8, and F11

DG incorporated diets: F3, F6, F9, and F12

NFE: Nitrogen free extract.

GE: Gross Energy, calculated as 5.65, 9.45 and $4.11 \mathrm{Kcal}$ per gram of protein, lipid and

carbohydrate, respectively (after NRC, 1993).

$\mathrm{P} / \mathrm{E}$ ratio: Protein to energy ratio (mg crude protein Kcal-1 GE). 
Yellow corn was finely milled. Pits were removed from the dates which divided then to equal parts, the first part was water washed, air dried, chopped in meat grinder, and then stored in plastic bags to represent wet cull date (WCD). The second part and date pits were dried in oven dryer at $60-80^{\circ} \mathrm{C}$ for $72 \mathrm{hrs}$, separately crushed in disc crusher, fine powdered with grain grinding mill, sieved and stored to represent dried cull date (DCD) and date pits (DP). Each ingredient was thoroughly mixed with other ingredients as formulated, then vitamins, minerals mixtures, MLE, or DG were added with continuous mixing, and few drops of soybean oil was added at the same time of mixing warm water $\left(45^{\circ} \mathrm{C}\right)$ which was slowly added until the diets began to clump. Diets were processed by a California pellet mill machine and dried for $48 \mathrm{hrs}$ at $70^{\circ} \mathrm{C}$ in a drying oven, producing particles size of $0.6 \mathrm{~mm}$ diameter and $2 \mathrm{~mm}$ length.

\section{Carcass analysis:}

At the beginning, about twenty fish were collected, immediately frozen and reserved for initial carcass analysis. On the other hand, in this study termination, all fishes in each aquarium were netted, weighed, frozen and kept for final carcass analysis. Fish samples were pulverized and homogenized with Ultra-Tunax, samples were oven dried at $60-80^{\circ} \mathrm{C}$ for $48 \mathrm{hrs}$ and whole body protein, lipid and ash were performed according to AOAC (2000) standard method.

\section{Measurement of growth:}

Growth performance parameters; weight gain, average daily gain (ADG), specific growth rate (SGR \%), feed conversion ratio (FCR), protein and energy utilization were determined according to Recker, (1975) and Castell \& Tiews, (1980).

Total gain $(\mathrm{g} /$ fish $)=(\mathrm{WT}-\mathrm{WI})$

Where: WT: Final means weight of fish in grams and WI: Initial means weight of fish in grams Average daily gain (ADG) $(\mathrm{g} /$ fish day-1) = total gain / duration period Specific growth rate $(\mathrm{SGR}) \%$ day-1) $=100 \times(\mathrm{Ln} \mathrm{WT}-\mathrm{Ln} \mathrm{WI}) / \mathrm{n}$.

Where: Ln: Natural log, n: is the duration period.

\section{Feed and nutrient utilization:}

Feed conversion ratio $(\mathrm{FCR})=$ dry matter intake $(\mathrm{g}) /$ total gain $(\mathrm{g})$.

Protein efficiency ratio $(\mathrm{PER})=$ total gain $(\mathrm{g}) /$ protein intake $(\mathrm{g})$

Protein productive value $(\mathrm{PPV} \%)=(\mathrm{PT}-\mathrm{PI}) \times 100 /$ Protein intake $(\mathrm{g})$

Where: PT: Protein content in fish carcass at the end;

PI: Protein content at the start.

Energy utilization $($ EU \% $)=($ ET-EI $) \times 100 /$ Energy intake $(\mathrm{kcal})$

Where: ET: Energy in fish carcass (kcal) at the end;

EI: Energy in fish carcass (kcal) at the start.

\section{Statistical analyses:}

The present study included two replications for each treatment in a completely randomized design. Analysis of variance of diets difference was 
performed according to Steel and Torrie (1980). Statistical analysis was applied using the SAS (1997) with factorial design including comparisons between significant means.

\section{RESULTS AND DISCUSSION}

\section{Water quality:}

Water quality parameters were suitable for rearing Nile tilapia as indicated by the results that obtained from periodical determination water quality parameters in the experimental glass aquaria: Temperature $\left(28 \pm 0.5^{\circ} \mathrm{C}\right)$, dissolved oxygen $(6.8 \pm 0.6 \mathrm{mg}$ $\mathrm{L}-1)$, total ammonia $(0.10 \pm 0.12 \mathrm{mg} \mathrm{L}-1)$, nitrite $(0.05 \pm 0.03 \mathrm{mg} \mathrm{L}-1)$, total alkalinity $(178 \pm 38 \mathrm{mg} \mathrm{L}-1)$, chlorides $(570 \pm 148 \mathrm{mg} \mathrm{L}-1)$ and $\mathrm{pH}(8.3 \pm 0.17)$. These results are in agreement with the results of to Abdelhamid (2009 a \& b).

\section{Growth performance:}

The effect of replacement, dried cull date (DCD), wet cull date (WCD) and date pits (DP) instead of yellow corn (YC), as energy sources, supplemented with MLE or DG as phytogenic feed additives; on growth performance of Nile tilapia (O. niloticus) fingerlings is summarized in Table (4) and Figs. (1\&2).

Concerning energy sources as the limiting factor for growth performance, it was observed that replacement either DCD or WCD instead of YC without additive supplementation improved fish growth performance significantly $(\mathrm{P} \leq 0.05)$, while it was decreased with DP replacement. In compatibility with the present study, Yousif et al., (1996) reported that the growth and feed efficiency of blue tilapia (O. aureus) fed dates and date pits-based diets were very poor.

Table 4: Effect of different energy sources (DCD, WCD, DP and YC) and incorporated phytogenic additives (MLE and DG) on growth performance of Nile Tilapia (O. niloticus) fingerlings.

\begin{tabular}{|c|c|c|c|c|c|c|c|c|c|c|c|c|}
\hline & \multicolumn{10}{|c|}{ Diets } & \multicolumn{10}{|c|}{ DCD } \\
\cline { 2 - 14 } L.S.D \\
\cline { 2 - 14 }
\end{tabular}

Mean in the same column bearing different superscript are significantly different at $(\mathrm{P}<0.05)$.

Control diets (without phytogenic additives): F1, F4, F7, and F10

MLE incorporated diets: F2, F5, F8, and F11

DG incorporated diets: F3, F6, F9, and F12

ADG: Average daily gain ( $\mathrm{g} /$ fish day- 1 )

SGR: Specific growth rate (\% day-1) BWi: Initial body weight BWf: Final body weight 
In comment, El-Sayed et al., (2006) on Nile tilapia and Shiau and Lin (1993) on O. niloticus x O. aureus hybrids concluded that the poor performances of fish fed date pits may be attributed to their high contents of simple sugars, whereas tilapia are known to utilize complex sugars more efficiently than simple sugars. Moreover, El-Sayed et al., (2000) suggested that the date pits carbohydrate may also contain amylase inhibitors, or other antinutrients that would reduce their utilization by tilapia.

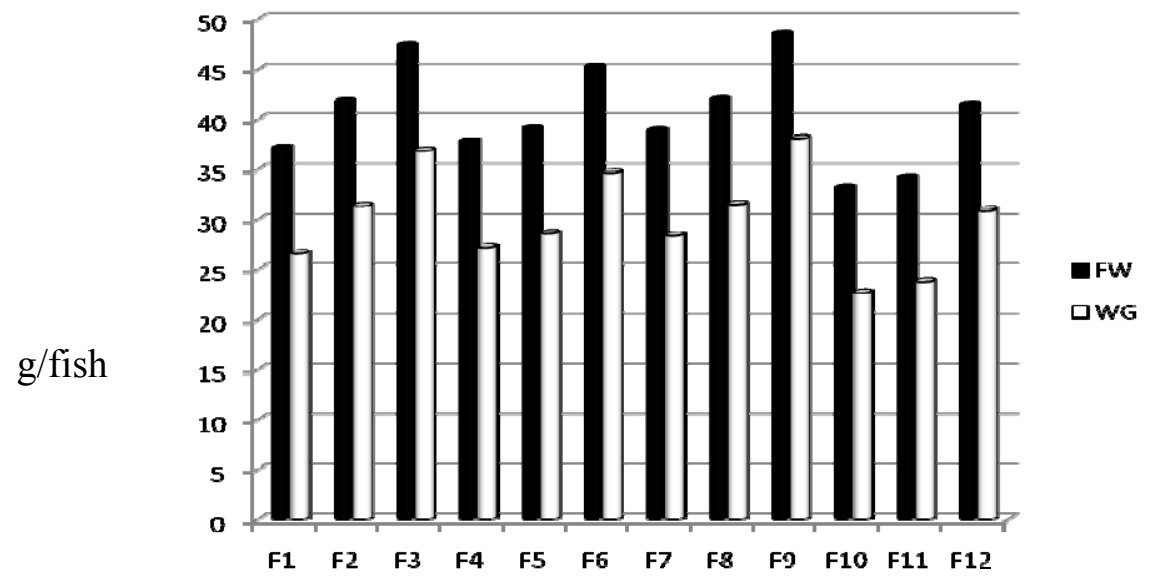

Feed number

Fig. 1: Final weight and weight gain

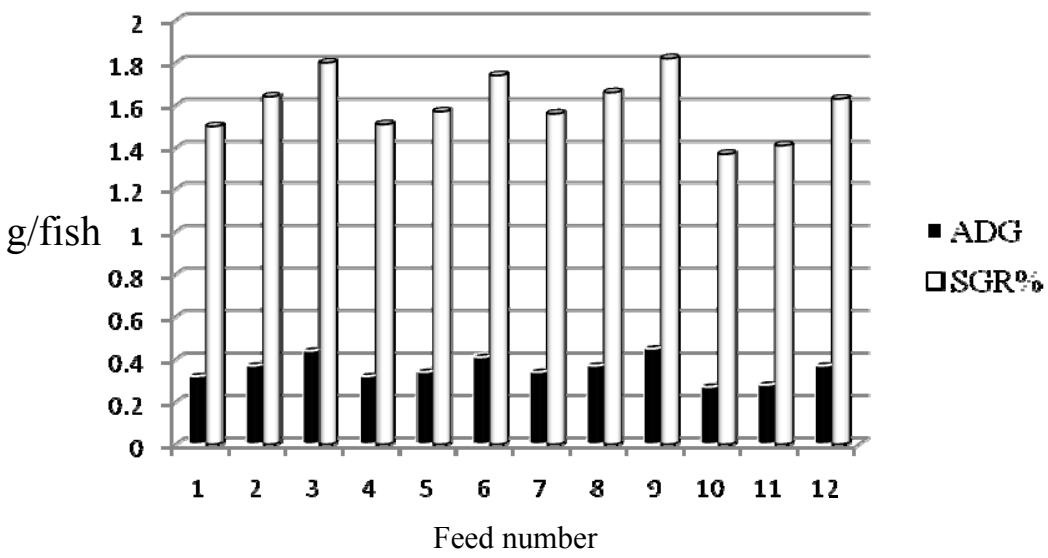

Fig. 2: Average daily gain and specific growth rate

On the contrary, Belal and Al Jasser (1997) found that the total replacement of date by-product instead of corn starch improved tilapia weight gain, feed conversion and protein efficiency ratio. Also, Osman et al., (2001) 
concluded that more than $15 \%$ date pits in Nile tilapia diets decrease the utilization values of the dietary protein.

Moreover, supplementation DG improved all energy sources utilization, where WCD-based diet (F9) recorded the highest values following by YC-based diet (F3), then DCD-based diet (F6) and the lowest was DP-based diet (F12).

The same trend was observed with supplementation different energy sources with MLE (F8, F2, F5 and F11, respectively). It seems that these results may be due to the impact of DG and LME, being run on increase digestibility of the feed supplied nutrients by increase gastric acid and enzymes secretions. Similar results have been reported for probiotics use in diets for tilapia by Carnevali et al., (2006); El-Dakar et al., (2007) and Salem, (2008).

On the other hand, fish fed WCD zero additives-based diet (F7) realized higher growth performance significantly $(\mathrm{P} \leq 0.05)$ among other fish fed this type of diets (F4, F1 and F10 in descending order). In agreement with the previous results, some studies on Nile tilapia (Al Asgah, 1988; Omar and Nour, 1993; Belal and Al Jasser, 1997) revealed that dates and its by-products could be used as a nutritional source for these fish.

\section{Feed and nutrient utilization:}

Table (5) and Figs. (3 \& 4) illustrate the influence of replacement 13.5\% DCD, WCD or DP instead of YC, supplemented with $0.03 \%$ MLE or DG or not as feed additives, on feed and nutrient utilization of Nile tilapia (O. niloticus) fingerlings.

Table 5: Effect of different energy sources (DCD, WCD, DP and YC) and incorporated phytogenic additives (MLE and DG) on feed and nutrients utilization of Nile tilapia fingerlings.

\begin{tabular}{|c|c|c|c|c|c|c|c|c|c|c|c|c|c|}
\hline \multirow{4}{*}{ Item } & \multicolumn{12}{|c|}{ Diets } & \multirow{4}{*}{$\begin{array}{l}\text { L.S.D } \\
(\mathrm{P}<0.05)\end{array}$} \\
\hline & \multicolumn{3}{|c|}{$\mathrm{YC}$} & \multicolumn{3}{|c|}{$\mathrm{DCD}$} & \multicolumn{3}{|c|}{ WCD } & \multicolumn{3}{|c|}{$\mathrm{DP}$} & \\
\hline & 0 & MLE & $\mathrm{DG}$ & D & MLE. & $\mathrm{DG}$ & 0 & MLE & $\mathrm{DG}$ & D & MLE & $\mathrm{DG}$ & \\
\hline & F1 & F2 & F3 & F4 & F5 & F6 & F7 & F8 & F9 & F10 & F11 & F12 & \\
\hline $\begin{array}{c}\text { Feed intake (FI) } \\
(\mathrm{g} / \mathrm{fish})\end{array}$ & $\begin{array}{l}43.91^{\mathrm{a}} \\
\pm 0.07 \\
\end{array}$ & $\begin{array}{l}49.46^{2} \\
\pm 3.00 \\
\end{array}$ & $\begin{array}{c}46.96 \mathrm{a} \\
\pm 0.9 \\
\end{array}$ & $\begin{array}{l}46.34^{\mathrm{a}} \\
\pm 1.71 \\
\end{array}$ & $\begin{array}{l}48.0 g^{a} \\
\pm 1.68 \\
\end{array}$ & $\begin{array}{l}49.84^{a} \\
\pm 0.74 \\
\end{array}$ & $\begin{array}{l}45.44^{a} \\
\pm 7.20 \\
\end{array}$ & $\begin{array}{l}49.09^{\mathrm{a}} \\
\pm 5.95 \\
\end{array}$ & $\begin{array}{l}47.48^{\circ} \\
\pm 2.40 \\
\end{array}$ & $\begin{array}{l}43.81^{2} \\
\pm 6.77 \\
\end{array}$ & \begin{tabular}{|l|}
$43.90^{\mathrm{x}}$ \\
\pm 8.46 \\
\end{tabular} & $\begin{array}{l}51.64^{a} \\
\pm 0.05 \\
\end{array}$ & 13.27 \\
\hline FCR & $\begin{array}{c}1.50^{\mathrm{a}} \\
\pm 0.01 \\
\end{array}$ & $\begin{array}{r}1.44^{a} \\
\pm 0.11 \\
\end{array}$ & $\begin{array}{r}1.16 a \\
\pm 0.01 \\
\end{array}$ & $\begin{array}{c}1.55^{4} \\
\pm 0.07\end{array}$ & $\begin{array}{r}1.53^{\mathrm{a}} \\
\pm 0.07 \\
\end{array}$ & $\begin{array}{r}1.31^{12} \\
\pm 0.01 \\
\end{array}$ & $\begin{array}{r}1.45^{2} \\
\pm 0.25 \\
\end{array}$ & $\begin{array}{r}1.42^{\mathrm{a}} \\
\pm 0.21 \\
\end{array}$ & $\begin{array}{c}1.13^{a} \\
\pm 0.07\end{array}$ & $\begin{array}{c}1.76^{b} \\
\pm 0.31 \\
\end{array}$ & \begin{tabular}{|c|}
$1.68 \mathrm{~b}$ \\
\pm 0.32 \\
\end{tabular} & $\begin{array}{r}1.52^{\mathrm{a}} \\
\pm 0.02 \\
\end{array}$ & 0.5337 \\
\hline PER & $\begin{array}{c}1.986 \\
\pm 0.01 \\
\end{array}$ & $\begin{array}{c}2.22^{6} \\
\pm 0.16 \\
\end{array}$ & $\begin{array}{c}2.57 a \\
\pm 0.02 \\
\end{array}$ & $\begin{array}{r}1.87^{\mathrm{d}} \\
\pm 0.08 \\
\end{array}$ & $\begin{array}{c}1.96^{6} \\
\pm 0.01 \\
\end{array}$ & $\begin{array}{c}2.29^{b} \\
\pm 0.03 \\
\end{array}$ & $\begin{array}{c}2.11^{\mathrm{b}} \\
\pm 0.34 \\
\end{array}$ & $\begin{array}{c}2.14^{b} \\
\pm 0.30 \\
\end{array}$ & $\begin{array}{c}2.64^{a} \\
\pm 0.13 \\
\end{array}$ & $\begin{array}{c}1.74 \\
\pm 0.27 \\
\end{array}$ & $\begin{array}{r}1.859 \\
\pm 0.37 \\
\end{array}$ & $\begin{array}{r}1.976 \\
\pm 0.02 \\
\end{array}$ & 0.609 \\
\hline PFV\% & $\begin{array}{l}31.44^{\circ} \\
\pm 0.09 \\
\end{array}$ & $\begin{array}{l}35.28 \\
\pm 2.55 \\
\end{array}$ & $\begin{array}{l}41.34 a \\
\pm 0.32 \\
\end{array}$ & $\begin{array}{l}29.246 \\
\pm 1.04 \\
\end{array}$ & $\begin{array}{l}31.00^{5} \\
\pm 0.11 \\
\end{array}$ & $\begin{array}{l}36.50^{\mathrm{b}} \\
\pm 0.42 \\
\end{array}$ & $\begin{array}{l}33.16^{\mathrm{b}} \\
\pm 5.29 \\
\end{array}$ & $\begin{array}{l}34.01^{\mathrm{b}} \\
\pm 4.69 \\
\end{array}$ & $\begin{array}{l}42.40^{1} \\
\pm 2.06\end{array}$ & $\begin{array}{l}27.10^{\mathrm{d}} \\
\pm 4.32 \\
\end{array}$ & $\begin{array}{l}29.38^{\circ} \\
\pm 5.86 \\
\end{array}$ & $\begin{array}{l}31.246 \\
\pm 0.31 \\
\end{array}$ & 9.504 \\
\hline EU\% & $\begin{array}{l}20.18 \\
\pm 0.06 \\
\end{array}$ & $\begin{array}{l}22.51^{\mathrm{b}} \\
\pm 1.63 \\
\end{array}$ & $\begin{array}{l}26.22 \mathrm{a} \\
\pm 0.21 \\
\end{array}$ & $\begin{array}{l}18.90^{\mathrm{d}} \\
\pm 0.66\end{array}$ & $\begin{array}{l}19.92 \\
\pm 0.71 \\
\end{array}$ & $\begin{array}{l}23.31^{\mathrm{b}} \\
\pm 0.27\end{array}$ & $\begin{array}{l}21.46^{b} \\
\pm 3.42 \\
\end{array}$ & $\begin{array}{l}21.976 \\
\pm 3.04 \\
\end{array}$ & $\begin{array}{l}27.15^{\mathrm{a}} \\
\pm 1.31 \\
\end{array}$ & $\begin{array}{l}17.62^{4} \\
\pm 2.80 \\
\end{array}$ & $\begin{array}{l}18.99 \mathrm{~d} \\
\pm 3.79 \\
\end{array}$ & $\begin{array}{l}20.11^{5} \\
\pm 0.20 \\
\end{array}$ & 6.142 \\
\hline
\end{tabular}

Mean in the same column bearing different superscript are significantly different at $(\mathrm{P}<0.05)$.

Control diets (without phytogenic additives): F1, F4, F7, and F10

MLE incorporated diets: F2, F5, F8, and F11

DG incorporated diets: F3, F6, F9, and F12

FCR: feed conversion ratio PER: protein efficiency ratio PPV\%: protein productive value EU\%: energy utilization 


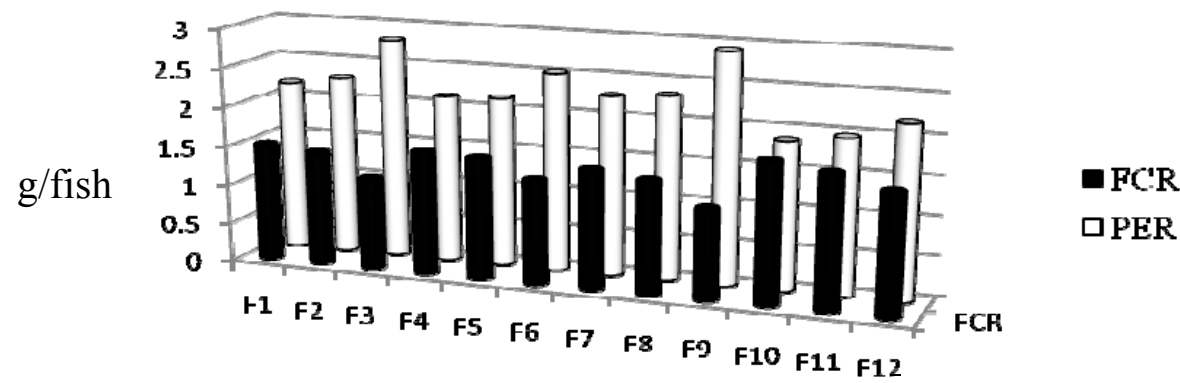

Feed number

Fig. 3: Feed conversion and protein efficiency ratios

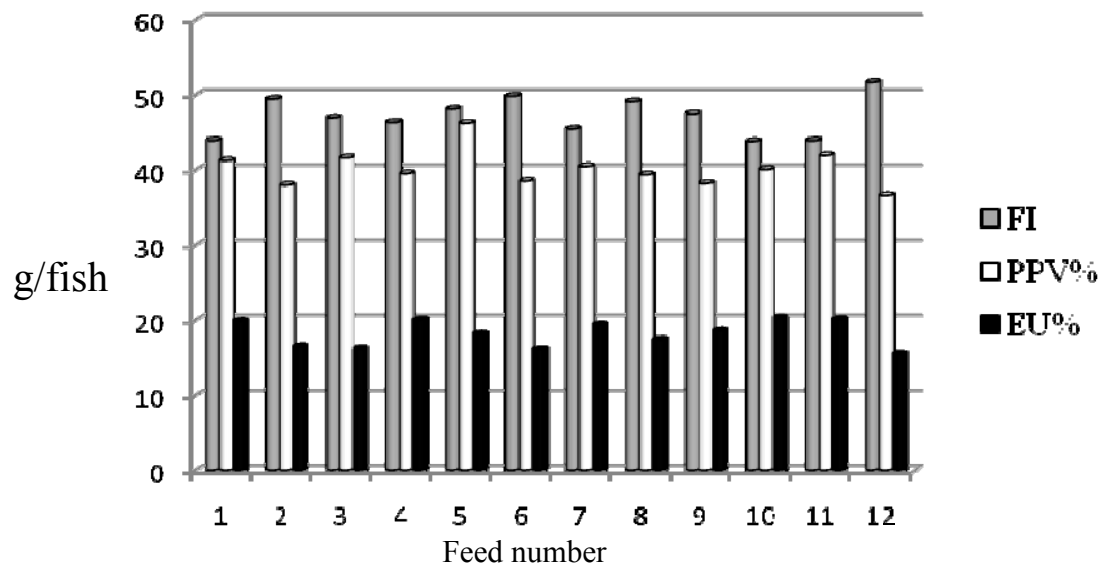

Fig. 4: Feed intake, protein productive value and energy utilization

Concerning to energy sources, the replacement of WCD instead of YC in Nile tilapia with zero additives-based diets improved fish feed and nutrients utilization, meanwhile replacement DCD or DP instead of YC decreased feed and nutrients utilization and FCR increased. In details, replacement 13.5\% WCD instead of YC in Nile tilapia with zero additives-based diets increased PER (2.11 vs.1.98), PPV\% (33.16 vs. 31.44) and EU\% (21.46 vs. 20.18), while replacement $13.5 \%$ DCD or DP instead of YC decreased PER (1.98 vs. 1.87 or 1.74 ), PPV\% (31.44 vs. 29.24 or 27.19) and EU\% (20.18 vs. 18.9 or 17.62), however FCR increased (1.50 vs. 1.55 or 1.76). On the other side, replacement $13.5 \%$ WCD instead of YC, supplemented with DG (F9) has optimized FCR (1.50 vs. 1.13), protein utilization (PER, 1.98 vs. 2.64; PPV\%, 31.44 vs. 42.40) and energy utilization (EU\%, 20.18 vs. 27.15) significantly $(\mathrm{P} \leq 0.05)$. In agreement, El-Sayed et al., (2006) indicated that the incorporation of raw date pits in Nile tilapia diets lead to poor feed utilization efficiency. In contrast, Sotolu et al., (2011) concluded that date seeds would be best used as a source of energy for 
improved feed utilization efficiency. Meanwhile, Al Asgah, (1988) found that date pits can replace wheat bran-barley mixture in common carp feed at up to $75 \%$ inclusion level, without any significant retardation in fish growth and feed utilization efficiency. In relation to that contradiction, El-Sayed et al., (2006) reported that the effect of dietary date pits on fish performance may be species specific as well the differentiation of chemical composition for date pits. In addition and according to Shiawoya and Adeyemi (2003); Sule and Sotolu (2010), low fiber content of feeds or ingredients could stimulate increased feed intake as well as enhance feed quality and digestibility. Although, in the present study, fish fed DP supplemented with DG-based diet (F12) ingested the highest amount of feed (51.64) that contains $4.58 \%$ crude fiber; the higher feed utilization achieved with fish fed the slightly higher crude fiber $(5.04 \%)$ diet (F9), which is in consistent with Dioundick and Stom (1990) who reported that tilapia has been shown to grow extremely well at up to $5 \%$ supplemental fiber.

In spite of being significantly $(\mathrm{P} \leq 0.05)$ lower than control diet, supplementation zero additives DP-based diets with either MLE or DG improved FCR, PER, PPV\% and EU\%; and fish fed DP-based diet supplemented with DG (F12) recorded the best feed and nutrients utilization significantly $(\mathrm{P} \leq 0.05)$ between DP-based diets group. Feed intake was not significantly different $(\mathrm{P} \geq 0.05)$ in all treatments. Furthermore, feed utilization of fish fed DG included diets was significantly $(\mathrm{P} \leq 0.05)$ better than those fed MLE included diets.

Indicating to the improvement in feed utilization followed by MLE or DG supplementation, it could be said that additives have improved feed efficiency; especially DP-based diets, which is reflected on fish feed and nutrient utilization.

\section{Carcass composition of fish:}

Chemical compositions of Nile tilapia whole body are presented in Table (6) and Fig. (5). No significant $(\mathrm{P} \geq 0.05)$ differences were observed between all treatments at the end of the experiment.

Table 6: Effect of different energy sources (DCD, WCD, DP and YC) and incorporated phytogenic additives (MLE and DG) on chemical composition of Nile tilapia fingerlings.

\begin{tabular}{|c|c|c|c|c|c|c|c|c|c|c|c|c|c|c|}
\hline \multirow{4}{*}{ Iteftrt } & \multirow{5}{*}{ At start } & \multicolumn{12}{|c|}{ Diet } & \multirow{4}{*}{$\begin{array}{c}\text { L.S.D } \\
(P<0.05)\end{array}$} \\
\hline & & \multicolumn{3}{|c|}{$\mathrm{YC}$} & \multicolumn{3}{|c|}{ WCD } & \multicolumn{3}{|c|}{ DCD } & \multicolumn{3}{|c|}{$\mathrm{DP}$} & \\
\hline & & 0 & MLE & $\mathrm{DG}$ & 0 & MLE & DIG & 0 & MLE & $\mathrm{DG}$ & 0 & IMLE & $\mathrm{DG}$ & \\
\hline & & F1 & $\mathrm{F} 2$ & F3 & F4 & FS & F6 & F7 & F8 & F9 & F10 & F11 & F12 & \\
\hline \multicolumn{14}{|l|}{ At. end } & \\
\hline \multirow[b]{2}{*}{$\mathrm{DM} \%$} & $23.80^{6}$ & $25.45^{n}$ & $25.64^{2}$ & $2592^{\mathrm{n}}$ & $25.33^{\mathrm{a}}$ & $25.52^{\mathrm{a}}$ & $25.76^{\mathrm{a}}$ & $25.40^{\mathrm{n}}$ & $25.60^{\mathrm{2}}$ & $25.90^{\mathrm{h}}$ & $25.12^{b}$ & $25.37^{\mathrm{x}}$ & $25.55^{\mathrm{a}}$ & \multirow[b]{2}{*}{0.6046} \\
\hline & \pm 0.224 & \pm 0.05 & \pm 0.15 & \pm 0.03 & \pm 0.10 & \pm 0.31 & \pm 0.44 & \pm 0.01 & \pm 0.06 & \pm 0.31 & \pm 0.18 & \pm 0.02 & \pm 0.10 & \\
\hline \multirow{2}{*}{$\mathrm{CP} \%$} & $53.80^{b}$ & $58.83^{4}$ & $59.00^{2}$ & 59.25 & $58.86^{2}$ & $59.95^{\circ}$ & $59.11^{12}$ & $58.86^{\mathrm{n}}$ & $59.13^{2}$ & $58.80^{2}$ & 58.65 & $58.87^{\circ}$ & $59.00^{\mathrm{n}}$ & \multirow[b]{2}{*}{0.7703} \\
\hline & \pm 0.028 & \pm 0.03 & \pm 0.11 & \pm 0.06 & \pm 0.29 & \pm 0.16 & \pm 0.34 & \pm 0.24 & \pm 0.17 & \pm 0.59 & \pm 0.06 & \pm 0.24 & \pm 0.22 & \\
\hline \multirow{2}{*}{ EE\% } & $22.54^{b}$ & $23.24^{\mathrm{n}}$ & $22.88^{6}$ & $22.53^{b}$ & $23.40^{\mathrm{a}}$ & $23.11^{\mathrm{a}}$ & $22.72^{\mathrm{b}}$ & $23.20^{\mathrm{n}}$ & $22.92^{\mathrm{b}}$ & $22.60^{\mathrm{b}}$ & $23.46^{\mathrm{a}}$ & $23.25^{\mathrm{a}}$ & $22.91^{b}$ & \multirow{2}{*}{0.5016} \\
\hline & \pm 0.042 & \pm 0.07 & \pm 0.08 & \pm 0.05 & \pm 0.03 & \pm 0.07 & \pm 0.07 & \pm 0.05 & \pm 0.11 & \pm 0.06 & \pm 0.01 & \pm 0.05 & \pm 0.08 & \\
\hline Ash \% & $23.66^{2}$ & $17.93^{6}$ & $18.12^{6}$ & $18.22^{\mathrm{b}}$ & $1796^{\circ}$ & $17.94^{6}$ & $18.1 \mathrm{~T}^{6}$ & $17.94^{6}$ & $17.95^{6}$ & $18.10^{6}$ & $1789^{6}$ & $17.88^{6}$ & $18.09^{6}$ & 0.3375 \\
\hline \multirow[b]{2}{*}{ GE (kcal 100 g-1) } & $516.21^{\mathrm{b}}$ & $551.2^{\mathrm{a}}$ & $548.8^{2}$ & $546.80^{2}$ & $5529^{2}$ & $550.6^{2}$ & $5479^{2}$ & $551.0^{2}$ & 549.92 & $551.0^{2}$ & $551.4^{2}$ & $551.1^{2}$ & $547.7^{\mathrm{a}}$ & \multirow[b]{2}{*}{3.126} \\
\hline & \pm 0.453 & \pm 0.65 & \pm 0.05 & \pm 0.66 & \pm 0.51 & \pm 1.19 & \pm 1.01 & \pm 0.17 & \pm 0.18 & \pm 0.74 & \pm 0.09 & \pm 0.26 & \pm 1.40 & \\
\hline
\end{tabular}

Mean in the same column bearing different superscript are significantly different at $(\mathrm{P}<0.05)$.

Control diets (without phytogenic additives): F1, F4, F7, and F10

MLE incorporated diets: F2, F5, F8, and F11 DG incorporated diets: F3, F6, F9, and F12

DM: Dry matter. CP: Crude protein EE: Ether extract GE: Gross energy. 


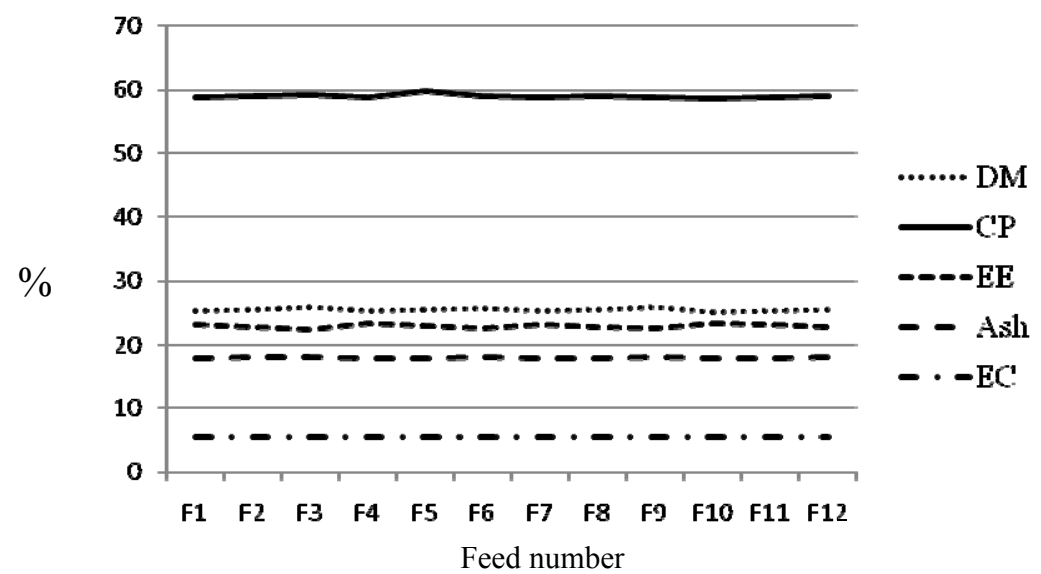

Fig. 5: Carcass analysis

No significant differences $(\mathrm{P} \geq 0.05)$ were observed between all treatments at the end of the experiment in DM\%, CP\%, ash\% and GE (kcal 100g-1), while fish fed DP-based diets showed the lower EE\% values and no significant differences $(\mathrm{P} \geq 0.05)$ were observed between fish fed DP-based diets whatever the energy source was. Meanwhile, no significant differences $(P \geq 0.05)$ were observed between fish fed zero additives-based diets whatever the energy source was. Results of Table (7) reveal that the highest EE\% value achieved with fish fed zero additives DP-based diet $(23.46 \%)$, while the lowest with those fed YCbased diet supplemented with DG $(22.53 \%)$.

In this connection, El-Gasim et al., (1995) explained the protein deposition in animal tissue may due to the hormonal effect of date pits as a repartitioning agent (acts in a similar way as estrogen) which alters the energy deposition towards protein and away from fat.

In support to the present results, El-Sayed et al., (2006) found that replacement different levels $(0,25,50,75$ and $100 \%)$ of raw date pits instead of wheat bran as energy source in Nile tilapia diets does not affect significantly $(\mathrm{P} \geq 0.05)$ crude protein carcasses in all treatments. In addition, the improving effect of probiotics has been reported by Eid and Mohamed, (2008) and Mohamed et al., (2007) in agreement with the results of the present study.

\section{Economic evaluation:}

Calculations of economical effeiciency of the tested diets based on the cost of feed and cost of one $\mathrm{kg}$ gain in weight of Nile tilapia and its ratio with the control group are shown in Table (7). Zero additives DP-based diet (F10) recorded the highest cost per kg gain (5.30 L. E kg-1).

The economic evaluation revealed the superiority of WCD-based diet supplemented with DG (F10) since it provides the least cost for producing one $\mathrm{kg}$ gain, followed by control diet supplemented with DG (F10). 
It was found that Nile tilapia could be produced cheaper when fed the control diet, the relative reductions in fish gain cost are calculated as 26.2 L.E. $/ \mathrm{kg}$ for F9 diet compared to the control diet (F1).

Table 7: Cost of feed required for producing one $\mathrm{Kg}$ gain of Nile tilpia fingerlings fed the experimental diets.

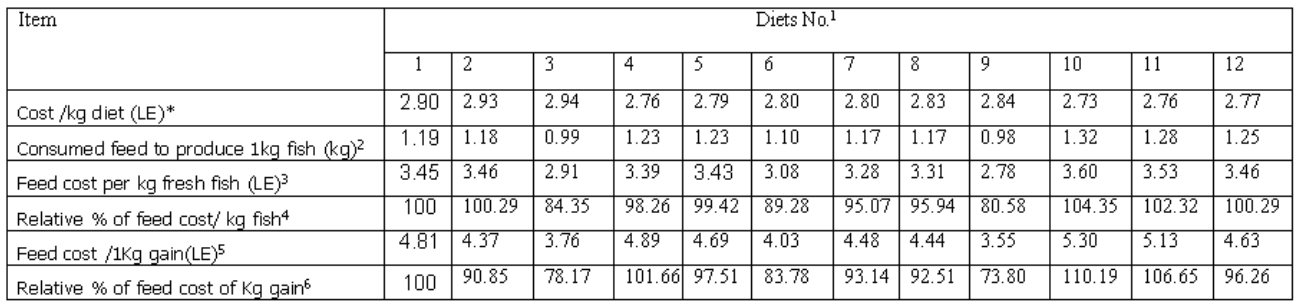

*Cost of $1 \mathrm{~kg}$ ingredients used were $6 \mathrm{~L} . \mathrm{E}$ for fish meal, 1.90 L.E for soybean meal, 1.75 L.E for yellow corn, 0.75 L.E for date unusable (DDU), 1 L.E for wet date (WD), 0.50 L.E for date stone (DS ), 100 L.E for Marjoram leave extract (MLE) , 120 L.E. for Digestarom ${ }^{\circledR}$ (D) ,6.5 L.E for soybean oil , and 5L.E for Vit \& Min.Egypt Feed Ingredients Price at start of 2009.

${ }^{1}$ Diet 1 . (control diet), diets 4,7and 10 contained $30 \%$ DDU, WD and DS ; diet 2.control diet with $0.03 \%$ MLE, diets 5,8 and 11 contained $30 \%$ DDU, WD and DS with $0.03 \%$ MLE and diet 3 .control diet with $0.03 \%$ D, diets 6,9 and 12 contained $30 \%$ DDU, WD and DS with $0.03 \% \mathrm{D}$, respectively.

${ }^{2}$ Feed intake per fish per period/ final weight per fish $\mathrm{Kg} / \mathrm{Kg}$

${ }^{3}$ Feed cost per $\mathrm{kg}$ fresh fish $(\mathrm{LE})=$ Cost $/ \mathrm{kg}$ diet $(\mathrm{LE}) \mathrm{X}$ consumed feed to produce $1 \mathrm{~kg}$ fish $(\mathrm{kg}) 2$

${ }^{4}$ Respective figures for step 3 / highest figure in this step.

${ }^{5}$ Feed cost $/ 1 \mathrm{Kg}$ gain $(\mathrm{LE})=$ Feed intake per $\mathrm{Kg}$ gain $\mathrm{X}$ Cost $/ \mathrm{kg} \operatorname{diet}(\mathrm{LE})$

${ }^{6}$ Respective figures for step $5 /$ highest figure in this step.

In agreement with Osman et al., (2001) and Abdel-Hakim et al., (2006), the present study's results indicate that the declined cost of one $\mathrm{kg}$ diet may be attributed to the low price of replaced non conventional energy sources instead of yellow corn.

On the other hand, El-Sayed et al., (2006) suggested that the expected reduction in the cost of DP-based diets may justify the use of this by-product in Nile tilapia feed, however the present results suggest the limited use of date pits in Nile tilapia feeds.

\section{CONCLUSION}

The results of the present study indicated that wet cull date (Phoenix dactylifera) is a good energy source, which could be partially replacing yellow corn in Nile tilapia diets for its positive effects in growth performance and feed utilization. At the same time, it could be inferred from the present study generally, that Digestarom ${ }^{\circledR}$ would serve as a good feed additive in Nile tilapia feeds. 


\section{REFERENCES}

Abdel-Hakim, N.F.; Azab; A.A.; Abdel-Wareth, K.H.F.; El-Kholy and Hayam Tonsy (2006). Effect of replacing yellow corn by dried carrots or dried carrot tops on growth performance of growing Nile tilapia (O. niloticus) Egypt. J. of Appl. Sci. 21 (6b): 455-469.

Abdelhamid, A.M. (2009-a). Fundamentals of Fish Production and Culture. New Universal Office, Alexandria, I.S.B.N. 977-438-052-5, 393 p.

Abdelhamid, A.M. (2009-b). Modern Approach in Aquaculture. New Universal Office, Alexandria, I.S.B.N. 977-438-053-3, 393 p.

Al-Asgah, N.A. (1988). "Date palm seeds as food for carp (Cyprinus carpio L.)," J. College Sci, King Saud Univ., 19: 59-64.

Al-Shahib, W. and Marshall, R.J. (2003). The fruit of the date palm: its possible use as the best food for the future? Inter. J. Food Sci. Nutrit., 54 (4): $247-$ 259

AOAC (2000). Association of Official Analytical Chemists, Official methoDP of analysis, 17th Ed. Washington, DC.,USA.

Azaza, M.S.; Mensi, F.; Kammoun, W.; Abd Elouaheb, A.; Brini, B. and Kraiem, M. (2008). Nutritional evaluation of waste date fruit as partial substitute for soybean meal in practical diets of juvenile Nile tilapia, $(O$. niloticus). Aquacult. Nutrit. Published Online: 2 Jun 2008, J. compilation (C) 2009 Blackwell Publishing.

Azaza, M.S.; Mensi, F.; Kammoun, W.; Abdelouahab, A.; Brini, B. and Kraiem, M. (2009). Nutritional evaluation of waste date fruit as partial substitute for soybean meal in practical diets of juvenile Nile tilapia, O. niloticus Aquacult. Nutrit., 15(3): 262-272.

Belal, I. E. H. and Al-Jasser, M. S. (1997). Replacing dietary starch with pitted date fruit in Nile tilapia, (O. niloticus) feed. Aquacult. Res., 28: 385-389.

Bown, D. (1995) Encyclopaedia of Herbs and their Uses. Dorling Kindersley, London. ISBN 0-7513-020-31.

Carnevali, O.; De Vivo, L.; Sulpizio, R.; Gioacchin, G.; Olivotto, I.; Silvi, S. and Cresci, A. (2006). Growth improvement by probiotic European sea bass juveniles (Dicentrarchus labrax, L.), with particular attention to IGF-1, myostatin and cortisol gene expression. Aquacult., 258: 430-438. 
Castell, J.D. and Tiewes, K. (Editor) (1980). Report of the EIFAC, IUNS and ICES Working Group on the standardization of Methodology in Fish Research, Hamburg, FRG,212-23 March, 1979. IFAC Tech. Pap. (3) 24.

Chiej, R. (1984). Encyclopaedia of Medicinal Plants. MacDonald, ISBN 0-35610541-5.

Dioundick, O.B. and Stom, D.I., (1990). Effect of dietary $\alpha$-cellulose levels on the juvenile tilapia, Oreochromis mossambicus (Peters)," Aquaculture, 91, pp. 311-315.

Eid, A. and Mohamed, K.A. (2008). effect of using probiotic as growth promoters in commercial diets for monosex Nile tilapia (O. niloticus) fingerlings. $8^{\text {th }}$ International Symposium on Nile tilapia in Aquacult.

El-Dakar, A. Y.; Shalaby, S. M. and Saoud, I. P. (2007). Assessing the use of dietary probiotic/prebiotic as an enhancer of spinefoot rabbitfish Singanus rivulatus survival and growth. Aquacult. Nutrit., 13: 407-412.

Elgasim, E. A.; AI-Yousef, Y. A. and Humeida, A. M. (1995). Possible hormonal activity of date pits and flesh fed to meat animals. Food Biochem., 52: 149-152.

El-Sayed, A.-F. M.; Moyano, F. J. and Martinez, I. (2000). "Assessment of the effect of plant inhibitors on digestive protease of Nile tilapia using in vitro assays" Aquacult. Intl., 8, pp. 403-415.

El-Sayed, A.F.M.; Hamza, W.R. and Al-Darmaki, M. (2006). Evaluation of date pits as a feed ingredient for juvenile and adult Nile tilapia (O.niloticus) reared in a recirculating system. Proceeding of $7^{\text {th }}$ Int. Symp. On Tilapia Aquacult.

FAO (1999). Food and Agriculture Organization of the United Nation. Date Palm Cultivation. FAO Plant Production and Protection Papers, Rome, $312 \mathrm{pp}$.

Fecka I. and Turek S. (2008). Determination of polyphenolic compounds in commercial herbal drugs and spices from Lamiaceae: thyme, wild thyme and sweet marjoram by chromatographic techniques. Food Chem. 108: 1039-1053.

Halle, I.; Thomann, R.; Bauermann, U.; Henning, M. und Köhler, P. (2004). Einfluss einer gestaffelten Supplementierung von Kräutern oder 
ätherischen Ölen auf Wachstum und Schlachtkörpermerkmale beim Broiler, Landbauforschung - Issue 4/2004.

Janicsak G., Mathe I., Miklossy-Vari V., Blunden G. (1999). Comparative studies of the rosmarinic and caffeic acid contents of Lamiaceae species. Biochem. System Ecol. 27: 733-738.

Mabrouk, H. A.; Labib, E. M. H. and Zaki, M. A. (2008). Nutritional Value of Prosopis juliflora Pods in Feeding Nile Tilapia (O. niloticus) Fries. Arab Gulf J. Sci. Res., 26 (1/2): 49- 62 (2008). Ref. No 2438.

Mabrouk, H. A.; Labib, E.M.H. and Zaki, M.A. (2011a). Response of Nile Tilapia mono-sex (O. niloticus) fingerlings to different Sources and Levels of Protein using Garlic and Onion as Feed phytoadditives, Arab Julf J.Sci. Res. Bahrain, (in press).

Mabrouk, H. A.; Labib, E. M. H. and Zaki, M. A. (2011b). Partial and Totally Replacement of Jojoba meal (Simmondsia chinensis) With Fishmeal in Nile tilapia (O. niloticus) Fingerlings Diets. J. Agricult. Sci. and Technol., USA. J. Agricult. Sci. and technology, USA, (in press).

Mohamed, K. A.; Badia Abdel Fattah and Eid, A. M. S. (2007). Evaluation of Using Some Feed Additives on Growth Performance and Feed Utilization of Monosex Nile Tilapia (O. niloticus) Fingerlings. Agricult. Res. J. Suez Canal Univ., 7 (3): 49-54.

Nour, A.A.; Srour, T.M. and Nour, A.M. (2004). Utilization of inedible dried dropping dates as a dietary energy source for blue tilapia (O. niloticus) reared in enclosure nets. J. Agric. Sci. Mansoura Univ., 29 (1): 73-82.

NRC (1993). Nutrient requirements of warm water fishes and shellfishes. National Academy Press, Washington DC.

Oladotun, O.A, Aina, A.B.J. and Oguntona, E.B. (2003). Evaluation of formulated agro-Industrial wastes as dry season feed for sheep. Nigerian J. Anim. Prod., 30: 71-80.

Omar, E., and Nour, A. (1993). Utilization of Droppings of immature date fruits in feeding of Nile tilapia (O. niloticus). The 3rd Symposium on the date palm, Saudi Arabia, January 17-20, 1993, Vol. II. Date Palm Research Center, King Faisal University, Al-Hassa, Mars publishing House, Riyadh, pp. 425-431. 
Osman, M. F.; Alhadrami, G. A. and Ben Zayed, A. A. (2001). Sulforic acid treated date pits as a dietary ingredient in Nile tilapia (O.niloticus) diets.Egyptian J. Nut. Feed (special issue): pp.753-754.

Recker,W. E. (1975). Computation and interpretation of biological statistics of fish population. Fish Res. Borard Can.Bull.,191.

Salem, M. E. M. (2008). Studies on some medicinal plants as mycotoxins in fish diets. M.Sc. Department of Animal Production. Thesis submitted to the Faculty of Agricult. University Kafr Elsheikh University.

SAS (1997). SAS/STAT Guide for personal computer. SAS Inst. Cary, N.C. (ISBN: 3-540-65014-8.Statistical Package for the Social Sciences, SPSS, USA.

Shiau, S.Y. and Lin, S.F. (1993). Effect of supplemental dietary chromium and vanadium on the utilization of different carbohydrates in tilapia, $O$. niloticus X O. aureus. Aquacult., 110: 321-330.

Shiawoya, E.L. and Adeyemi, A.A. (2003). Nutrient composition of mixed forages growing on Bosso Campus of the Federal University of Technology (FUT) Minna, Niger State, Nigeria. Science Forum: J. P. app. \& Sci., 6 (2): $213-218$.

Steel, R.G. and Torrie, J.H. (1980). Principles and procedures of statistics. McGraw Hill Book Co., New York.

Sotolu, A.O. and Faturoti, E.O. (2009). Digestibility and Nutritional Values of Differently Processed Leucaena leucocephala (Lam. de Wit) Seed Meals in the Diet of African Catfish (Clarias gariepinus). Middle-East J. Sci. Rese., 3 (4): 190-199.

Sotolu, A.O. (2010). Growth Performance of Clarias gariepinus (Burchell, 1822) Fed Varying Inclusions of Leucaena leucocephala Seed Meal, Tropicultura, 28 (3): 168-172.

Sotolu, A.O.; Kigbu, A.A. and Oshinowo, J.A. (2011). Nutritional Evaluation of date Palm (Phoenix dactylifera) seeds and fruits as source of feeds in Aquacult. EJEAFChe, 10(5), 2011 [2279-2285].

Srour, T.M.; Zaki, M.A. and Nour, A.A. (2002). Dried droppinf dates as a dietary energy source for Nile tilapia (O. niloticus) and African catfish 
(Clarias gariepinus). The 1st Annual Scientific Conf. Anim.and Fish Prod. Sept.24 and 25, Al-Mansoura, Fac. Agricult.

Sule, S. O. and Sotolu, A.O. (2010). Nutritional Evaluation of Snail Offal Meal as Animal Protein Supplement in the Diets of Clarias gariepinus (Burchell, 1822) Fingerlings, World Journal of Fish and Marine Sci., 2 (2): 103-108.

Thakare, M. N. (2004). Pharmacological screening of some medicinal plant as antimicrobial and feed additives .M.Sc. Department of Animal and Poultry Science. Thesis submitted to the faculty of the Virginia Polytechnic Institute and State University .

Yousif, O. M.; Osman, M. F. and Alhadrami, G. A. (1996). Evaluation of date and date pits as dietary ingredients in tilapia (O. aureus) diets differing in protein sources. Biores. Technol., 57: 81-85. 